\title{
THE MEDIATING ROLE OF CONSENT IN BUSINESS MARKETING
}

Stefanos Mouzas and David Ford

\author{
Available online
}

Industrial Marketing Management

https://doi.org/10.1016/j.indmarman.2018.03.011

\begin{abstract}
The study deepens our understanding of business marketing by looking beyond the individual choices of business actors to the role of consent between interacting actors. Based on an empirical investigation of manufacturers and retailers in Germany and drawing from previous research on business relationships, the paper develops a theoretical structure for the analysis of consent in business marketing. The paper argues for a shift from a view of individual choice as the basis of business marketing towards the idea of choice being part of an evolutionary discursive practice of consent. The study detects the mediating role of consent at four levels: 1) as a stratifying process, 2) as recursive practice, 3) as energizing interaction, and 4) as economizing activities, resources and actors; it elaborates significant theoretical implications and highlights managerial lessons.
\end{abstract}

\section{INTRODUCTION}

This paper examines how the giving and receiving of consent between companies affects business marketing. Consent means that an agreement among actors has been reached; hence, consent occurs when an actor agrees to a proposal made by another actor. For example, in the annual trade negotiations between manufacturers and retailers, consent occurs when upon a 
retailer's request, a manufacturer agrees to offer private labels or bespoke consumer and trade promotions to a retailer; or for example, when a retailer agrees to distribute manufacturer brands or provide incremental shelf for brand extensions that a manufacturer has proposed. Similarly, consent occurs when business actors agree to develop environmentally friendly offerings, develop new business, enter new segments, or distribution channels. In all these examples, the giving and receiving of consent between interacting business actors would affect their individual choices. For this reason, informed and voluntary consent matters in several contexts, such as in business, law, research, medicine, as well as personal relationships (Barnett, 1986; Buchanan \& Tullock, 1999; Donaldson \& Dunfee, 1994; Scary, 2014); thus, consent is regarded as the foundation for the legal enforceability of contracts (Barnett, 1986, 1992; Bar-Gill, 2012; Mouzas \& Blois, 2013; Mouzas, 2016).

We posit that consent between companies is one of the missing pieces of the puzzle of what happens when business marketers and their business customers seek a jointly agreed action. There is a scarcity of discussion about the role of consent in business marketing because our hitherto understanding in marketing has largely been shaped by the choice perspective (Child, 1997; Beckert, 1997; Williamson, 2002). The choice perspective centers on the decisionmaking processes of corporate and individual business actors. The choice perspective builds on the core theoretical constructs of corporate direction, industry and competition analysis (Ansoff, 1970; Porter, 1981; 2008; Pettigrew, 2014). Specifically, in marketing the choice perspective was initially expressed in terms of the 'marketing decision variables' (Howard, 1957) which evolved into the concept of a marketing-mix (Kelley \& Lazer, 1958) and the "four P's" (McCarthy, 1960; Kotler 1967) that business actors would apply. Nonetheless, the choice perspective has been mediated by a continuing debate about the connectivity between the actor and its context (Hamel \& Prahalad, 1990; Barney, 1991). Previous debates have been 
confronted by calls to develop relational perspectives that recognize the interdependencies among individually significant customers and suppliers within complex inter-firm networks (Håkansson et al., 2009; Day, 2000; Ford \& Mouzas, 2013; Lush, Vargo \& Tanniru, 2010; Johanson \& Vahlne, 2011).

Drawing from relational perspectives on business networks and conducting an empirical investigation on business relationships between manufacturers of consumer brands, such as Mars, Kellogg, Nestlé, and Unilever as well as grocery retailers, such as Wal-Mart, Metro, Rewe, Lidl and Aldi (Villas-Boas \& Zhao, 2005), we ask the following research question: How does the giving and receiving of consent between suppliers and customers affect their business marketing?

By addressing this research question, the present study develops a theoretical framework that seeks to advance our understanding of the mediating role of consent in business marketing. The study challenges common beliefs about actors' independent decision-making and contributes to the theory of business marketing by highlighting the mediating role of consent as: 1) stratifying process, 2) recursive practice, 3) energizing interaction, and 4) economizing activities, resources and actors. The contribution brings new insights into an interactive practice through which multiple consents are sought, modified and given between variously interconnected counterparts. This contribution is relevant today because at a time of rapid advances in telecommunication and global interconnectivity between suppliers and customers, it complements and re-directs the idea of choice in business marketing away from a discrete and independent decision-making towards the idea of choice being part of an evolutionary discursive practice of consent among business actors. 


\section{FROM CHOICE TO CONSENT}

The choice perspective is concerned with how actors make choices. Williamson (2002, p. 172) identifies two parallel theoretical constructions within the choice perspective: "the theory of consumer behavior, in which consumers maximize utility, and the theory of the firm as a production function, in which firms maximize profit". The choice perspective emphasizes actors' free will and autonomy rather than their connectivity and interdependence within business relationships (Håkansson et al., 2009; Ford et al. 2011; Ford \& Mouzas, 2013; Uzzi, 1997; Uzzi \& Lancaster, 2003). For example, the choice perspective postulates that it is up to individual companies to choose how to develop and launch innovative products; decide for the right price and promotions; and choose their channels of distributions; it also is up to individual managers to choose their course of marketing action. Consequently, the choice perspective assumes a 'stimulus-response function' in which changes in relative prices, products, promotions and distributions influence responses of the market and thus the profits of the firm.

James Buchanan was among the first scholars to recognize a preoccupation with such a 'science of choice', as opposed to an examination of how actors achieve the "mutuality of advantage from voluntary exchange" (Buchanan, 2001, p. 29). Buchanan's observation has relevance today because globalization and advances in telecommunication have increased the inter-connectivity in the business landscape. In today's context, the limitation of choice perspective becomes apparent when we consider the evidence of the dynamic co-evolution that takes place between the wills of actors who need to co-exist in an increasingly interconnected world and whose co-existence and development is inter-twined (Nowak, 2006, 2011). Consider for example, the co-evolution between major suppliers and major customers (Lusch, Vargo \& Tanniru, 2010; Mayer \& Argyres, 2004; Volberda \& Lewin, 2003). A major supplier of electric batteries, for example, would co-exist and co-evolve with other car manufacturers and 
manufacturers or consumer electronics. Similarly, a retailer, such as Marks \& Spencer, would co-exist and co-evolve with multiple manufacturers willing to produce private labels for Marks \& Spencer. Choice-centric views on business relationships take a generalized view of the market or the competition. In practical terms, this means that the choice perspective considers the market as a faceless topology in which companies compete with each other to maximize their profits.

In contrast, stakeholder theory (Freeman, 1984) relates the actor to specific counterparts whether customers or suppliers (Sharma \& Henriques, 2005). Moreover, attempts to draw from Giddens' (1984) ideas on structuration has provided an alternate perspective to examine in a more nuanced way the continuing interaction between the actor and its counterparts. This more 'external orientation' in research has also led to debate about the influence of the individual firm on wider processes in the business landscape (Håkansson, Olsen \& Bakken, 2013; Denrell, Fang \& Winter, 2003; Johanson \& Vahlne, 2011). These processes are largely nondeterministic and place clear limits on managers' ability to achieve change in any particular direction (Pettigrew, 2014; Caldwell, 2005; Mantere \& Vaara, 2008).

\section{THE CONCEPT OF CONSENT}

Our starting point is a view of consent as a reciprocal interactive process between companies. Through giving, receiving or denying consent to others, companies seek to address the challenges and problems that they face; for example, find new sources of revenues, expand distribution, develop and launch new products or services, and reduce operating costs. Consider a consumer goods company that seeks the consent of a major retailer for an in-store test of a new product line. Conversely, consider a machinery supplier that may refuse consent when one customer seeks to develop a new innovative production process but may agree to a 
similar proposal from another customer in return for an exclusivity agreement. The complexities of the business landscape mean that consent is not an instantaneous event that involves hard edges of "yes" or "no" choices, but an evolving interactive process over space and time. The examples illustrate that consent places business marketing into a network of interconnected and interdependent companies (Uzzi, 1997; Uzzi \& Lancaster, 2003; Zaheer \& Venkatraman, 1995; Venkatraman \& Camillus, 1984; Håkansson \& Snehota, 1989). For this reason, we posit that the study of consent in business marketing would require an investigation of involved 1) Actors, 2) Resources and 3) Activities within interconnected business relationships (Håkansson \& Snehota, 1995; Håkansson et al., 2009; Ford \& Mouzas, 2013). We also posit that the analysis of consent would require consideration of space and time; this would allow us to examine the co-evolution that takes place within an interconnected business landscape (Volberda \& Lewin, 2003; Ford \& Mouzas, 2010).

\section{The Components of Consent}

Consent in business marketing occurs as a combination of two broad components:

The Moral Component of Consent: Consent between business companies serves to legitimize their interaction as well as their individual actions. More fundamentally, consent is the "moral component that distinguishes between valid and invalid transfers of alienable rights" (Barnett, 1986, p. 270). This means that the use of other actors' resources would require their consent. This applies to physical resources as well as knowledge-based resources (Mouzas \& Ford, 2012). For example, using another actor's land to build a warehouse would require the property owner's consent; using a creative design or audio-visual product for commercial purposes would require the originator's consent. As different cultures might interpret consent in different ways, consent needs to be specified and manifested. The consent may specify how resources are be acquired, used or transferred to others; whilst the manifestation of consent may establish 
a "relation of recognition and respect" among counterparts (Markovits, 2004, p.1417). In contrast, the absence of consent may lead to an uncontrolled theft of tangible or intangible assets, innovations or designs or methods without any reward to the owners of those resources. The moral component of consent is widely institutionalized through legal registration of patents, copyrights and brands. The moral component of consent is also widely manifested in the tacit or explicit codes of conduct that develop within particular trades, professions, guilds and between incumbent market members.

The Instrumental Component of Consent: The instrumental component of consent operates as a way station through which business actors allow, authorize or acquiesces to the proposal of a counterpart to combine, adapt or exploit resources to which they are not otherwise entitled. Thus, the instrumental component of consent is regarded the foundation of contracting among actors (Barnett, 1986, Mayer \& Argyres, 2004; Mouzas, 2016). For example, by consenting to retailers' proposal to establish a continuous stock replenishment, manufacturers authorize retailers to replenish the volume of products that retailers need to operate their business. Instrumental consent is an intrinsic part of interaction and can take a similar variety of forms to wider interaction itself (Mantere \& Vaara, 2008. Thus at one extreme, consent may be a single acquiescence at a particular point in time to a counterpart's proposal, involving limited or major adaptation by either or both counterparts in interaction. Both the request for and the giving of consent may be clearly articulated or implied. For example, consenting to a standard form contract implies the acceptance of the terms and conditions defined by the counterparty. In contrast, consent can also form part of an interactive process involving multiple and evolving reciprocal proposals and counter-proposals over time and in a variety of contexts. For example, when manufacturers and retailers negotiate the cooperation in the production of private labels, multiple proposal and counter-proposals will evolve with regard to the property rights of the 
jointly developed products. In this way, consent may be simultaneous or jointly given. Finally, the impact of consent may not be limited to dyadic interactions and have wider effects on other business interactions and the interconnected companies, for example through consenting to subcontracting in the supply chain.

\section{METHODS}

The empirical study concerns manufacturer-retailer networks involving producers of fastmoving consumer goods and food retailers in Germany. The evidence illustrates the interconnections between the process of consent and the companies' business marketing.

\section{Material and Social Context}

Manufacturer-retailer networks in Germany comprise manufacturers, such as Mars, Kellogg, Nestlé, and Unilever, and retailers, such as Wal-Mart, Metro, Rewe, Lidl and Aldi (Villas-Boas $\&$ Zhao, 2005). These networks center on fast-moving consumer goods, which are subject to frequent product and marketing innovations, and unpredictable changes. Manufacturer-retailer networks for consumer goods in Germany generate an annual turnover of $€ 122$ billion in a market of 82,114,224 consumers (Statistisches Bundesamt, 2017).

\section{Sampling process}

Two manufacturers and two retailers form our sample to study the role of consent in business marketing. We have chosen this sample in line with existing research on business networks (Håkansson et al., 2013; Johanson \& Vahlne, 2011; Ford et al., 2011; Ostendorf et al., 2014). Extant research on business networks emphasizes the need to move beyond the examination of dyadic relationships and examine the impact of dyadic relationships on other interconnected relationships (Andersen al., 1994; Borgatti \& Foster, 2003; Håkansson et al., 2009). The two manufacturers and two grocery retailers offered a suitable sample for observing the giving and 
receiving of consent and the associated interactive processes within a manufacturer-retailer network (see Figure 1). The selected manufacturers and retailers are pioneers in the development and distribution of innovative fast-moving consumer goods. Manufacturer Primus is a multinational business company focused on full-priced snack foods while General Foods is a nationally important manufacturer of a wide range of food products. Discount Retailers focus private labels while Sunways is a grocery retailer with a focus on large hypermarkets and a diversified assortment of products. Conceptually, this granular sample comprised entrepreneurial actors actively engaged as protagonists in venturing with new and unique products and services.

Manufacturer Primus is a multinational business company focused on full-priced, branded snack foods while General Foods is a nationally important manufacturer of a wide range of food products. Discount Retailers focus on private labels while Sunways is a grocery retailer with a focus on large hypermarkets and a diversified assortment of products. We identified initial respondents from trade conferences. Subsequently, we added new respondents within the organizations according to their potential contribution to the development of theory. In total, we identified and engaged over a two-year period with 12 different respondents, representing two manufacturers and two retail groups (see Figure 1). 
Figure 1: Manufacturer-Retailer Network

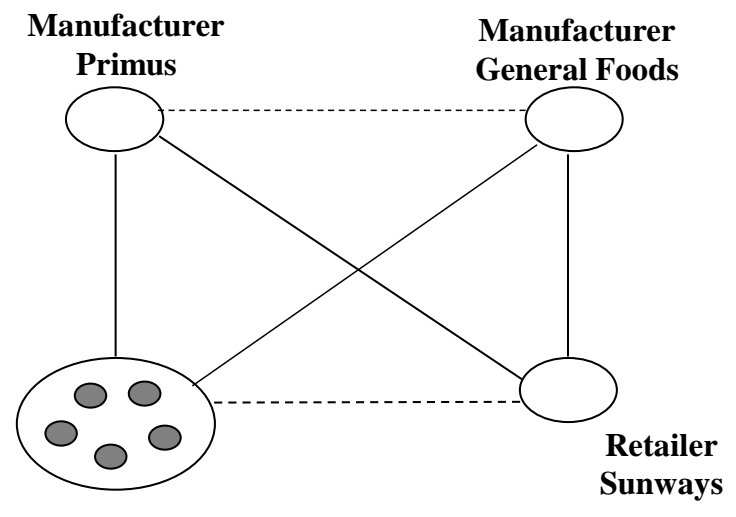

Discount Retailers

\section{Data Collection}

Data collection approach: We used the case study method (Tsoukas, 1989; Ragin \& Becker, 1992; Gibbert, Ruigrock \& Wicki, 2008) to employ a two-year engagement with practitioners and participant observation, conduct interviews with respondents and collect archival records as manifestations of consent (memoranda of understanding, minutes and contracts). Combining these techniques provided a way to collaborate with respondents, such as Business Managers, 
Category Managers and Account Managers, and generate understanding about their experiences (Cope, 2005, 2011). This approach was particularly suited to the purposes of the present research because we investigated the role of consent in business marketing within the real-life context of manufacturer-retailer networks. In this context, the boundaries between phenomenon of consent and the material and social context are not clearly evident. Consequently, multiple sources of evidence are needed, and triangulation of evidence is indispensable (Eisenhardt \& Graebner, 2007).

Data Collection: One member of the research team, who had local knowledge and prior work experience in the industry, conducted participant observation, interviews with practitioners and collected manifestations of consent. Gaining access to manufacturer-retailer networks was difficult. Discount Retailers were particularly secretive and reluctant to release sensitive archival information. Engaging with the respondents involved a major shift in the researcher's role to that of observer rather than participant. Prior local knowledge and ties, however, facilitated the identification of appropriate sources of information. We used participant observation, interviews and archival records to develop a contextual epistemology and evidence-based explanation of the role of consent in business marketing. We logged 78 field observations (including impromptu chats and meetings) about how the practice of consent occurs, the forms that consent takes and the variety of contingencies into a field-tracking system shortly after they occurred. We also collected 267 press releases, 8 annual reports and obtained 28 electronic copies of manifestations of consent (framework agreements) between manufacturers and retailers. We stopped collecting data when for the purpose of our research question a theoretical saturation had been reached. 
Table 1: Overview of Data Collection

\begin{tabular}{|l|l|}
\hline Companies/ Group of companies & 4 Manufacturers and retailers \\
\hline Respondents & 12 Managers \\
\hline Field observations & 78 Chats, Meetings, Events \\
\hline Press releases & 267 Press Releases \\
\hline Annual reports & $8 \quad$ Annual reports \\
\hline Manifestations of consent & $28 \quad$ Framework Agreements \\
\hline
\end{tabular}

When we finished the first draft of the study, we conducted feedback interviews with the senior managers to check our interpretations. This feedback proved extremely relevant in fine-tuning our interpretations and testing the internal validity of our findings.

\section{Data Analysis}

Consistent with previous work on studying networks of business relationships (Borgatti \& Foster, 2003; Uzzi \& Lancaster, 2003; Ford \& Håkansson, 2013), and in line with studies on qualitative methods (Silverman, 2000; Gibbert, Ruigrock \& Wicki, 2008), our data analysis involved a productive interplay between three elements: 1) empirical evidence, 2) the theoretical shift from choice to consent, 3) the research question on the role of consent in 
business marketing. The process of making sense of our findings encountered three challenges: 1) the problem of inter-firm complexity, 2) the problem of time (periodic interactions over time) and 3) comparison of findings. We observed that giving and receiving consent by suppliers and customers was exceedingly stratified, time-consuming and complex because interactions between companies were individualized, recurrent and often unpredictable. Both sampling and theoretical framework were conducive to our effort to address this challenge: firstly, we focused on the interactions between two producers and two retailers and examined the dynamics of the observed network, as well as the inter-connections in clusters to generate reliable comparisons. Secondly, we develop a theoretical structure to analyze our observations on giving and receiving consent in space and time. The purpose of our analysis was to identify the mechanisms that generated the events that we observed. The method of inference by postulating mechanisms, which are capable of generating the events, we observed, is referred to as 'retroduction' (Bhaskar, 1978; Sayer, 2000). We re-categorized our empirical observations of actors, resources and activities in space and time; then we classified them according to the chronological events list that we used in our data collection. This systematic and guided process of data analysis allowed us to connect concrete empirical observations of phenomena with abstract theoretical notions (Ragin \& Becker, 1992). 


\section{EVIDENCE FROM MANUFACTURER-RETAILER NETWORKS}

The companies that we investigated had all worked in the field of consumer goods for many years; each company was a major operator in their specific field of business with distinct capabilities, backgrounds, experiences and roles (see Table 2).

Table 2: Respondents' Business, Background and Function

\begin{tabular}{|l|l|l|l|l|}
\hline Companies & Business & $\begin{array}{l}\text { Capabilities/ } \\
\text { Experience }\end{array}$ & Respondents & Role \\
\hline Primus & Manufacturer & $\begin{array}{l}\text { Branded full- } \\
\text { priced snack food } \\
\text { products }\end{array}$ & $\begin{array}{l}\text { Klaus } \\
\text { Edward } \\
\text { Wolf }\end{array}$ & $\begin{array}{l}\text { KAM } \\
\text { Marketing } \\
\text { Production }\end{array}$ \\
General Foods & Manufacturer & $\begin{array}{l}\text { Private labels and } \\
\text { value food } \\
\text { products }\end{array}$ & $\begin{array}{l}\text { Dieter } \\
\text { John } \\
\text { Johann }\end{array}$ & KAM \\
Finance \\
R\&D
\end{tabular}

Manufacturer Primus is a successful multinational producer of fast-moving consumer goods and has built its business based on the basis of premium brands in the category of snack foods. Primus had invested over $€ 200$ million in the development of innovative snack foods in the 
previous three years. During this time, Primus had also invested over $€ 100$ million annually in advertising in order to create brand awareness for its innovative products. Primus had a presence in 180 countries, strong support from its US parent company and a market share of circa $33 \%$ in the category of snack foods in Germany. Primus' declared principle was to be the market leader or the major challenger/contender for that place in each product category in which it operated.

General Foods is Primus' main competitor. General Foods is a manufacturer of national importance represented in many product categories of food. General Foods has a highly developed production site in Germany as well as excellent Research \& Development facilities. However, their brands in the category of snack foods are weak and their market shares of circa $5 \%$ had been declining over the previous three years. As a generalist producer, General Foods produces private labels for a number of Discount Retailers. Private label business provides volume for manufacturer General Foods and contributes towards full utilization of its production capacities. But the private label business is less profitable, with operating margins of 5-10\% compared with branded brands for which operating margins of 40-50\% are common. Moreover, Discount Retailers possess property rights over private labels and thus can dictate all terms and conditions about how private labels are manufactured and sold.

Sunways is a grocery retailer focused on large retail hypermarkets of more than $4000 \mathrm{~m}^{2}$ and a diversified assortment of food and non-food products. Retailer Sunways' assortment includes both branded and private labels, but branded full-price products remain Sunways' core business at $85 \%$ of its total.

80 million Consumers in Germany and those elsewhere faced economic uncertainty related to the financial crises after many years of growth in their incomes and spending power. Purchase behavior and brand loyalty were increasingly being affected by consumers' emphasis on price, 
by the growth in availability of discount stores and by growing awareness of environmental concerns.

\section{Developing Private Label Snack Foods}

Retailer Sunways' financial performance had deteriorated in the years following the economic crisis of 2008. As consumers' price sensitivity increased, the demand for low-price products and private labels soared. Nielsen data showed that the growth rate for private labels was $15 \%$ annually. Sunways traced their dismal performance to their loss of competiveness in the retail business and the rise in demand for private labels within Discount Retailers. Discounters were not a new problem for Sunways because the discount segment had been increasing its share in recent decades. Sunways had not expected the sudden acceleration in private label demand. Discount Retailers' assortment of products consisted of $80 \%$ private labels offered at $60 \%$ of the price of the equivalent branded products, which they also had in their assortment. Sunways' new top management team was committed to restoring the hypermarkets' competitiveness. Suddenly, Sunways started to view private labels business as a way of offering competitive prices and regaining consumer preferences in highly competitive product categories. Sunways did not have its own manufacturing capabilities so it needed innovative and flexible manufacturers capable of delivering their requirements in snack foods. Retailer Sunways was reluctant to ask manufacturer General Foods to produce private labels for them, as General Foods already produced for their competitors, the Discount Retailers. Instead, Sunways' new top management considered that collaboration with manufacturer Primus would be a business opportunity because Primus was a world-leading innovative company and a preferred supplier of branded products for Sunways. Nonetheless, Sunways' category managers who had been 
with the retailer for many years were not enthusiastic about the idea of introducing private labels with Primus. They knew from previous annual trade negotiations in 2007 and 2008 that manufacturer Primus' policy was to build its own strong brands and not to produce private labels for other retailers under the slogan: "We don't produce our products for anyone else".

\section{Pursuing the opportunity of private labels}

Pursuit of business opportunities presented by private labels involved a number of proposals, responses, and re-responses by several companies. The giving and withholding of consent enabled, constrained, encouraged or facilitated the counterparts' business marketing. The subsequent interactions between retailer Sunways, manufacturer Primus, manufacturer General Foods and the Discount Retailers illustrate this process:

May 2009, Retailer Sunways: Sunways' Category Manager for Snack Foods, Franz Josef was instructed to develop plans to pursue the business opportunity of private labels. Sunways' purchasing and finance departments worked out the financial implications of various price/volume options. A series of internal meetings focused on the feasibility and viability of the private labels opportunity. The business case was supported by the assumption that private labels would result in produce incremental revenues and improved margins as a result of lower prices. The investment analysis also took into account the low opportunity cost of capital for Sunways (the cost of not investing in other opportunities with similar systemic risk).

Retailer Sunways' Board of Directors gave its consent to the proposal to open of formal negotiations with manufacturers in August 2009.

September 2009: Retailer Sunways and Manufacturer Primus: Sunways started to seek the consent to their proposal from Primus by using its annual trade negotiations with Manufacturer 
Primus. Sunways pointed out that the volume of business between the two counterparts was declining and that they both needed to discover new ways to address increasing consumer demand for low-price products. Sunways' Category Manager Franz Josef presented market research evidence that consumers' price-sensitivity was increasing rapidly and that after the economic crisis of 2008 private label business represented a business opportunity that was worth pursuing. He claimed that: "these new circumstances require new unconventional pathways".

Category Manager Franz Josef sought manufacturer Primus' consent to jointly develop and market three innovative snack food product lines as private labels that could generate up to 15 $\%$ incremental revenues and 30\% incremental profits. He said that if Primus agreed to develop and market innovative private labels, Sunways would vigorously support these business initiatives with $10 \%$ incremental shelf space for Primus and extensive point-of-sale promotions including permanent price-reductions and point of sale visibility.

October 2009: Retailer Sunways and Manufacturer Primus: Primus' Director of Key Account Management Klaus did not consent to Sunways' request to produce private labels, explaining that they did not have permission from the US parent company. Instead, Klaus proposed the launch of a series of new highly innovative snack food branded products, which he claimed would command a premium price. Klaus argued that: "In these new circumstances, we will pursue unconventional pathways with our unique brands that generate strong consumer off-takes".

Klaus presented prototypes of the new innovative products and a detailed launch plan that was supported by heavy media investments. Klaus finalized his presentation with a pledge: 
"We will check the attractiveness of the proposal with a market test and will conduct a pilot study that will guide a subsequent roll-out of the initiative”. Retailer Sunways' management was not surprised by this reaction but they felt distracted by the vigorous counter-initiative of the manufacturer. Sunways demanded more robust evidence that there was a business opportunity in new brands that was worth pursuing before it would consent to the counterinitiative.

December 2009: Retailer Sunways and Manufacturer Primus: Test market results for the new branded products from Primus were encouraging in terms of generating strong consumer interest. Consumer off-take data revealed a volume increase of $28 \%$ in the test group versus a control group. Despite this evidence, Sunways did not consent to Primus' launch of new products in their retail outlets. Retailer Sunways was faced with the rapid rise of Discount Retailers and they argued that the manufacturer's initiative was addressing the wrong problem. The retailer felt that innovative value products within private label business were a neglected business and that any delay in taking bold action would diminish Sunways' capability to compete in an exceedingly price-sensitive business landscape. According to retailer Sunways: "As retailers, we are representatives of consumer demand and need to respond to market developments". To convey this message to manufacturer Primus more emphatically, Sunways unilaterally delisted seven Primus' product items introduced during 2009. Category Manager Franz Josef then renewed his attempt to seek the consent of manufacturer Primus to a partnership with Sunways in developing and launching private labels.

April 2009: Retailer Sunways and Manufacturer General Foods: Following the disappointing outcome of their attempt to seek the consent of manufacturer Primus, retailer Sunways invited manufacturer General Foods to work with them in the area of private labels. 
The two companies reached consensus on two relevant insights: firstly that the increasing pricesensitivity of consumers dictated new responses; and secondly, that any new proposition should build on unique and innovative products able to generate strong consumer interest. Both counterparts agreed to move into the next phase of jointly developing and evaluating feasible options as soon as possible.

June 2010: Retailer Sunways and Manufacturer Primus: By the time of the second Quarterly Business Review between retailer Sunways and Primus, Primus' business revenues with retailer Sunways had decreased by $24.6 \%$ compared with the previous year. Sunways Category Manager Franz Josef notified Primus' Key Account Director Klaus that because of this dismal performance the manufacturer was about to lose the status of "Category Captain" in their stores. This title indicates the status of preferred supplier for a leading manufacturer and entailed privileges in terms of collaboration, influence on store planograms, the merchandising, promotion and pricing policies.

July 2010: Retailer Sunways and Manufacturer Primus: Manufacturer Primus continued to lose business with retailer Sunways. Primus’ Key Account Director Klaus felt captive within the existing business relationship with retailer Sunways. As Sunways delisted the newly introduced Primus' product items, the decline of Primus' business in Sunways' hypermarkets accelerated. Klaus felt that his company was being prevented by Sunways from pursuing their marketing of innovative, full-priced premium brands in the snack foods product category. Primus made a final attempt to convince Sunways' top management that simply imitating Discount Retailers would reduce consumer choice and would ultimately harm the overall product category of snack food as well as retailer Sunways. This attempt had no effect. Primus' Key Account Director Klaus realized that there was no joint vision between the businesses or 
any prospect of consent to a joint course of action. To break out of his perceived 'captivity', Klaus sought to develop business in the alternative channels of distribution such as Gas Stations, Hotels, Restaurants, Cafes (HORECA) and Convenience Stores. These outlets were growing in importance because of changes in customer shopping habits and increasing mobility. The effort to pursue new business opportunities with HORECA and Convenience Stores did produce incremental revenue, but generated lower profitability than business with retailer Sunways because of the increased logistical and sales force costs of obtaining and managing business with smaller and geographically dispersed outlets.

September 2010: Retailer Sunways and Manufacturer Primus: In September 2010 during the annual negotiations for the year 2011, Primus' Key Account Director Klaus sought retailer Sunway's consent to a new, account-specific marketing. This involved the launch of an exclusive mega-pack product (with three times of the original volume offered at $15 \%$ lower net-net price) that would only be available in the retail outlets of Sunways. Category Manager Franz Josef welcomed the Primus initiative as a step in the right direction; nonetheless, he could not consent to it on the grounds that the proposition would not sufficiently help Sunways compete with Discount Retailers that sell primarily private labels. Hans, the Purchasing Manager for Sunways added categorically:

“We simply can't ignore that private labels are priced at $60 \%$ of full-priced brands".

\section{October 2010: Retailer Sunways and General Foods}

Meanwhile, Sunways' Category Manager Franz Josef had been surprised by General Foods' initiative to offer an exclusive brand for retailer Sunways at private label price (60\% of fullpriced brands) instead of a private label. General Foods' proposal envisaged that the manufacturer would assume all $R \& D$ costs and that the brand will be sold exclusively within 
Sunways. Franz Josef welcomed the initiative as constructive move but a few days later, Retailer Sunways lawyers drafted a formal dissent letter to General Foods explaining that the proposition would be viable only if General Foods would consent to transfer the intellectual property rights for the proposed brand to retailer Sunways.

December 2010: Each of the three counterparts, Sunways, General Foods and Primus wished to avoid starting 2011 without a framework agreement between them. Discussions led to the following consents between them:

\section{The Consents between Sunways and Primus:}

Manufacturer Primus would produce an exclusive mega-pack for Sunways at a permanently low price (equivalent to $60 \%$ of the price of full-price brands). In return, retailer Sunways agreed to distribute all Primus' new innovative products at full-price. Primus would remain Category Captain within Sunways; and their collaboration would be extended to include the discounted segment.

\section{The Consents between Sunways and General Foods:}

General Foods would develop and produce an exclusive brand for retailer Sunways offered at $60 \%$ of full-price brands. Research and development costs would be shared by the two counterparts, and intellectual property rights would remain with the manufacturer for the first five years but would then be transferred to the retailer. Nielsen consumer data published in March 2011 indicated that Sunways exclusive brand and mega-pack offer were effective in gaining strong consumer demand. 
Discount Retailers were wary of these developments but adopted a "wait-and-see" attitude. However, during the annual trade negotiations that started in September 2011, Discount Retailers gave their consent to manufacturers for a listing of a number of manufacturer brands with strong consumer demand provided that they were supported by price promotions. The share of manufacturer brands within Discount Retailers' assortment rose by ten percent during that year.

\section{DATA ANALYSIS AND DISCUSSION}

This research uses a conceptual framework built on the three elements of actors, activities and resources to examine how business marketing evolves as an interactive process of consent over time, as illustrated in Table 3.

Table 3: Evidence of Consent in Business Marketing

\begin{tabular}{|c|c|c|}
\hline $\begin{array}{l}\text { LAYERS OF } \\
\text { INTERACTION }\end{array}$ & $\begin{array}{l}\text { INITIAL SITUATION IN } \\
\text { NETWORK SPACE }\end{array}$ & $\begin{array}{l}\text { INTERACTION OVER } \\
\text { NETWORK TIME }\end{array}$ \\
\hline ACTORS & $\begin{array}{l}\text { - Existing jointness between } \\
\text { General Foods and Sunways } \\
\text { in developing value brands } \\
\text { and private labels } \\
\text { - } \\
\text { Existing jointness between } \\
\text { Primus and Sunways in } \\
\text { developing premium brands } \\
\text { - Existing jointness between } \\
\text { Discount Retailers and } \\
\text { General Foods seeking } \\
\text { value products/ private } \\
\text { labels }\end{array}$ & $\begin{array}{l}\text { - Co-evolution between } \\
\text { Sunways and Primus, } \\
\text { initially constrained by goal } \\
\text { incompatibility } \\
\text { - Co-evolution between } \\
\text { Sunways and General } \\
\text { Foods initially constrained } \\
\text { by continuing co-evolution } \\
\text { between General Foods and } \\
\text { Discount Retailers } \\
\text { Evolving consumer } \\
\text { demand and counterparts' }\end{array}$ \\
\hline
\end{tabular}




\begin{tabular}{|c|c|c|}
\hline & & $\begin{array}{l}\text { performance affect co- } \\
\text { evolution of counterparts }\end{array}$ \\
\hline RESOURCES & $\begin{array}{l}\text { - } \begin{array}{l}\text { Sunways lacks private label } \\
\text { resources }\end{array} \\
\text { - General Food dependent on its } \\
\text { private label resources and } \\
\text { relationships with Discounters. } \\
\text { - } \begin{array}{l}\text { Discount retailers lack brand } \\
\text { resources. }\end{array}\end{array}$ & 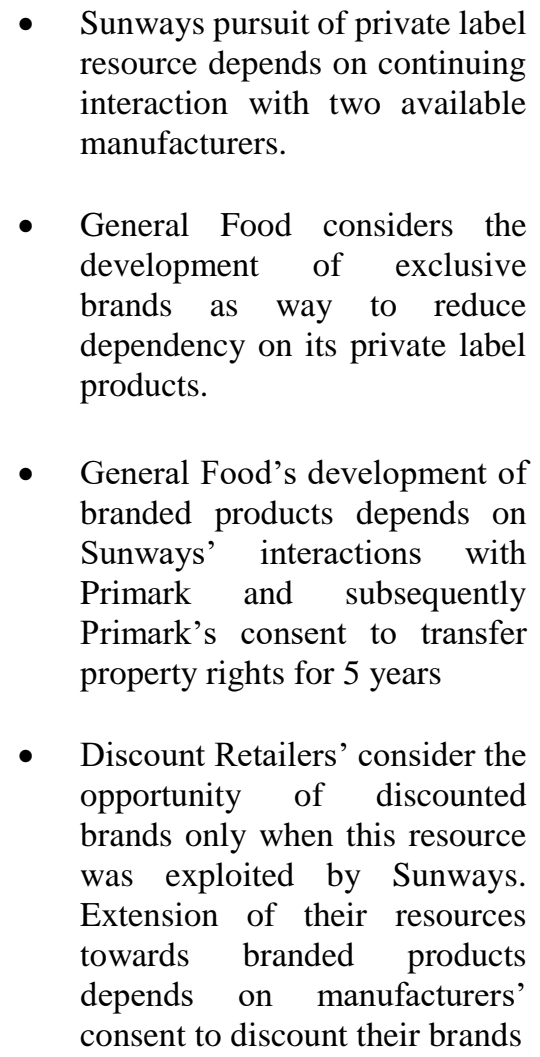 \\
\hline ACTIVITIES & 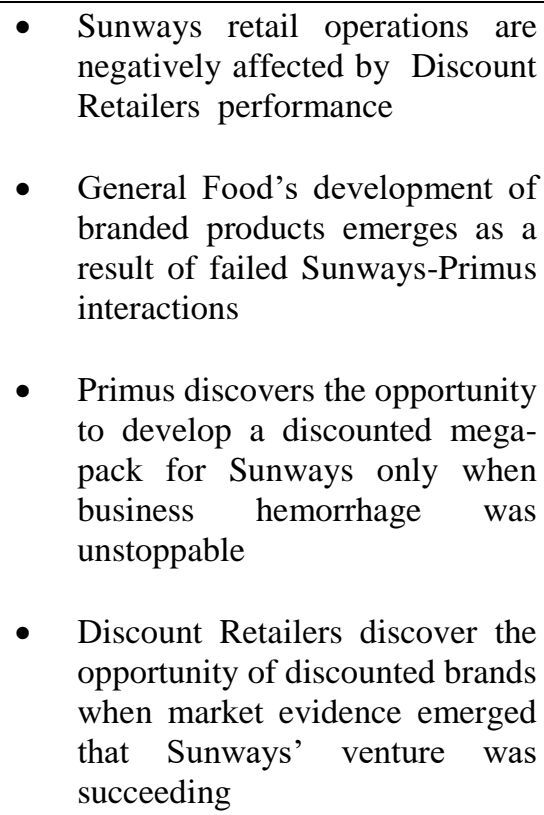 & 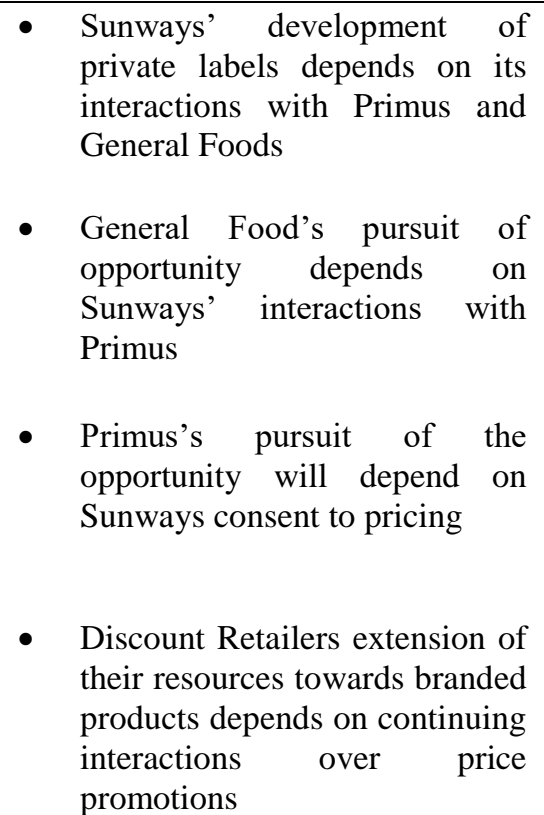 \\
\hline
\end{tabular}


Table 3 shows some of the multiplicity of interactions between business companies within the general spatiotemporal context of a global recession and enhanced consumer price sensitivity. The interactions examined are those between the activities, resources and individual and corporate actors that make up manufacturers Primus and General Foods and retailers Sunways and Discount Retailers.

Our starting point is the situation of network space in 2008. This situation and the position of the companies within it is the outcome of multiple interactions over many years, each built on an evolving pattern of supplier-customer relationships and a pattern of proposals, consents, refusals, subterfuges. Each of the relationships at this time is comprised of complex actor bonds between individuals and subgroups, ties between company resources and links between their activities.

Sunways management team needed to address the sharp decline in its own business performance and relationship with its retailer customers. Sunways traced this decline to the rise in demand for private labels developed by Discount Retailers. But a move towards private labels could only be achieved if Sunways could obtain the consent to a change in the path of resource evolution, activity specialization and actor jointness with one or both of only two potentially capable manufacturers. Sunways had existing relationships and well-developed actor bonds (Hite \& Hesterly, 2001; Cho \& Hambrick, 2006; Wilson, 2004). The business marketing of the two retailers and the two manufacturers Primus and General Foods were enabled and constrained in their approach to each other by the prior interactions and developed relationships between them. For example, Sunways' category managers knew from previous annual trade negotiations in 2007 and 2008 that manufacturer Primus' policy was not aligned with Sunway's intent to develop private labels. 
Table 3 illustrates some of the ways in which the initiatives of each of the involved companies: Sunways, Primus, General Foods, the Discount Retailers and of value-seeking Consumers. Interactions between the actors, activities and resources of the companies proceeded as a stepwise process of proposal and response which incorporated previous, anticipated, achieved and modified consents. The practice of interactive consent linked the initiatives of particular companies to the structure of the business landscape. This highlights the interpretation of business marketing as "effectuation processes" that take "a set of means (resources, actors, activities) as given" and focuses on the effects that can be co-produced with that set of means (Sarasvathy, 2001, p. 245). This brings us to the essence of business marketing as a continuing process of consent between interacting actors which serves to deploy resources through new means-end relations.

The intellectual lens of consent provides for in-depth analysis into these 'effectuation processes' and to identify how business actors discover and act upon possibilities to achieve mutuality of advantage (Barnett, 1986; Buchanan, 2001). Specifically, the study provides evidence that business marketing takes the form of multiple, nested threads of consent practices through which actors address current problems or respond to the initiatives of counterparts. Examples of these problems in the case study are provided by Sunways' lack of competitiveness in the segment of private labels; Primus' decline of business in Sunways' hypermarkets or General Foods' need to develop stronger brands. As well as the positive consents of companies to the proposals of counterparts, the case study also shows the role of negative responses to actors' initiatives in the evolution of business relationships and the wider business network. Examples include the Primus dissent to offer private labels, Sunways' dissent to Primus' launch of new products in their retail outlets or Sunways' request that the 
intellectual property rights for the products were transferred from General Foods to retailer Sunways. For firms innovative products are engines of growth and competitiveness because they generate attention and interest among consumers (Hoffmann and Broekhuizen, 2010; Sorescu, Chandy and Prabhu, 2003; Ostendorf et al., 2014).

The study provides evidence that actors' approaches evolved as an opportunity to deploy new means-end relations (Kirzner, 1997). This development followed a period of agonizing with mounting problems, such as deterioration of performance compared with particular competitors. Despite the impact of exogenous shocks on business performance (such as the economic crisis in 2008/9), business marketing did not follow simply from individual company decisions but was enacted on the basis of an interactive process of multiple consent-giving and receiving over time. In other words, business marketing was mediated by the consent of counterparts. For example, Sunways' management did not simply choose to enter the business of private labels. Similarly, manufacturer General Foods did not simply choose to boost branded products and Discount Retailers did not simply reconsider their private label choices. Instead, the initiatives of actors that we first observed as events were subject to the consent of others that enabled, constrained or revised the actors' intentions.

To move the analysis of data towards theoretical implications, we built on Tsoukas' (1989) work on the validity of idiographic explanations and considered the role of consent as a 'generative' mechanism that produced the events that we observed. Processes of consent answer 'why' and 'how' certain events in business marketing occur; they are the necessary mechanisms of acting in a set of contingencies (Pawson \& Tilley, 1997). This is evidenced in the consents between retailer Sunways and manufacturers Primus and General Foods and the consent between Discount Retailers and their manufacturers. 


\section{THEORETICAL IMPLICATIONS}

The case evidence suggests that the mediating role of consent is detected at four levels: firstly as a stratifying process; secondly as recursive practice; thirdly as energizing interaction and fourthly as economizing activities, resources and actors.

\section{(1) Consent as a Stratifying Process}

The consents recorded between retailers and manufacturers were neither instantaneous nor independent of each other. Consent giving and receiving involved a series of time-consuming and interconnected initiative-response-and-re-responses between multiple actors. Hence, consent generated a stratifying process with multiple interconnected threads. More fundamentally, the evidence of a stratifying process of interaction is in line with the theoretical shift away from economic inevitability (Sarasvathy, 2001). Conceptions of economic inevitability (Davidsson, Delmar \& Wiklund, 2006; De Rond \& Thietart, 2007) build on a science of choice that assumes causation processes that "take a particular effect as given and focus on selecting between means to create that effect" (Sarasvathy, 2001, p. 245). The evidence of multiple, parallel, interconnected threads of interaction illustrates effectuation processes that take inherent resources, actors, activities and focus on co-production of aspiring effects (Sarasvathy, 2001). The observation of stratifying process of interaction through consent differs diametrically from individualistic choice models of decision-making (Porter, 1981, 2008; Pettigrew, 2014).

\section{(2) Recursive practice}

Consent generates a recursive practice manifested by the repetitiveness of interaction, evidenced as periodic meetings, performance reviews, quarterly business reviews as well as 
annual negotiation processes. Table 3 highlights the recursive ways in which business interaction emerges in relational space and evolves 'time and again' as actors seek to address their problems and pursue opportunities that are subject to the consent of other actors. A consequence of recursive practice is that business marketing does not appear as collection of isolated, unrelated fine-grained practices in which time is simply a linear process. Instead, we can observe that actors' business marketing takes place as a recurrent pattern of episodes, incidents, joint action and reviews within continuously evolving social and material structure (Johanson \& Vahlne, 2011). Therefore, business marketing emerges as a process that takes place within a temporal frame that stretched years into the past and the future.

\section{(3) Energizing interaction}

The case study indicates that business marketing is likely to be interactive, multi-actor, multifaceted and irregular in both its frequency and significance. This is in line with previous work on choice, chance, and inevitability (De Rond \& Thietart, 2007 p. 546) that points out that business initiatives emerge "as a result of (unplanned) interactions between the consequences of choices made by various, sometimes unrelated, actors". Questions remain about the role of human agency; and how interactions enable business marketing to evolve. Consent affects the process of business interaction but does not have a single direction. Consent energizes subsequent interactions because it rests on an inter-cognitive achievement between actors. If actors' actual meeting of minds is based on informed and voluntary consent, then the prospect of counterparts' mutual gains will guide and speed up subsequent interactions (Mnookin, Peppet, \& Tulumello, 2000). The energizing role of consent supports scholarly work that pertains to the co-creation of business opportunities (Tan \& Tan, 2005); as well as the 
theoretical implications for negotiating and developing trust with one's co-creators (Hite \& Hesterly, 2001).

\section{(4) Economizing activities, resources and actors}

The case study indicates that consent economizes activities, resources and actors (Håkansson, Olsen \& Bakken, 2013). Table 3 provides examples of how the giving and receiving of consent redirects actors' initiatives and how actors, resources and activities are dynamically reconfigured to increase productivity. The evidence indicates 'discursive practices' that include challenging traditional practices, objectifying benefits and means-end relations and reframing cooperation (Vaara, Kleymann, \& Seristö, 2004; Vaara, E., \& Tienar, 2008). New activities emerge and existing ones may be adapted as proposals or responses to proposals in continuing relationships. These proposals and responses maintain or alter actors' less productive specializations. Proposals and responses are human interactions that could lead to changes in the division of labor and re-allocation of entitlements. Specifically, we observed the initial reluctance of manufacturer Primus to develop an exclusive offering for Sunways because Primus wished to remain a specialized provider of non-customer-specific, full-priced brands. Because opportunities that business actors discover are idiosyncratic (Denrell et al., 2003), the development of Sunways' private labels depended on which manufacturer would consent to their proposals. Similarly, the productivity of General Foods would depend on Sunways' retail resources in hypermarkets. These resources and the entitlements held over them are reshaped over time and redirected towards more productive uses. For example, Primus consented to move from ubiquitous brands to a customer-exclusive offering and General Foods consented to the transfer of property rights to Sunways after five years. The evolution of consent also affects the characteristics of actors themselves in space and time as in changes in the characterization of Primus as a manufacturer of brands or General Foods' as simply a producer 
of products. The economizing of activities, resources and actors (Håkansson et al., 2013) is evidenced in the evolving movement of retailers into roles traditionally performed by manufacturers and vice versa.

\section{Choice and Consent}

The importance of seeking the consent of counterparts in the evolution of business marketing does not remove the role of choice (Rond \& Thietart, 2007; Sminia \& De Rond, 2012) or reduce its importance for business success. Business marketers face clear choices about their overall approach to consent, the ways in which they will seek and give it and the variations in consent they will expect in different areas of their operations. Seeking the consent of others inevitably places limits on discretion which business actors are willing to accept to a greater or lesser degree. Business marketing involves a trade-off between retaining independence and flexibility at the expense of limiting access to or adapting the resources of others. Similarly, the giving of consent provides benefits to others and may involve costs of adaptation (Buchanan, 1979; Brennan \& Turnbull, 1999). Business marketing requires clarity in complex and multiple choices between viewing business as a zero-sum game or one of mutual gain. The giving and seeking of consent involves trade-offs between short and long term benefits for each business actor and its counterparts. These trade-offs require business actors to take a view of the evolution of their relationships and their wish to take or give short or long-term benefits. Therefore, consent is not a neutral phenomenon and all consent exists within a framework of understanding. All organizations operate with a consent on the basis of their own and their counterparts' resources; and all organizations have to deal with consent based on the resources of their counterparts. Thus by consenting to be dependent on the resources of others, organizations are able to develop a productive co-evolution with other organizations, rationalize their respective resources and achieve joint gains. 


\section{MANAGERIAL IMPLICATIONS}

The findings from this study highlight four important managerial lessons: Firstly, the study reemphasizes the interdependence between companies. Therefore, business interaction is a research tool as well as a vehicle for business marketing. Seeking the necessary consent of others in business marketing is not a single event. Instead, consent is a process that evolves through interaction, often with multiple interconnected counterparts. The centrality of role of consent in business marketing suggests that actors need to reverse the conventional sequence of taking positions, finding out the issues, and then perhaps ignoring the interests of their counterparts. Instead, helping the other side meet its "behind-the-table" challenges (Sebenius, 2013 p.7 ), business actors need to: 1) identify the hidden interests of their counterparts, 2) address issues jointly, and 3) avoid taking positions prematurely. Consent has multiple strands. Consent is sequential and cumulative. These characteristics suggest that companies need to review the past and potential future effects of consent on their activities, resources and actors themselves. The willingness to stand back and review evolving consent may enable business actors to avoid the common problem often expressed as, "How on earth did we get into this position”!

Secondly, the study indicates that business marketers and purchasers need to express and manifest their consent in such a way that their reasonable expectations are stated with certainty and predictability for their counterparts; and they need to include mechanisms for periodic business reviews and re-negotiation to deal with unforeseen contingencies. For example, in the context of international marketing, different cultures might have a different deduction of the concept of consent; manifestations of consent, periodic reviews and renegotiation mechanisms 
might address misunderstandings and unforeseen eventualities. In this way, business contracts create relevant reference points (Hart \& Moore, 2008; Fehr, Hart \& Zehnder, 2011) and enhance firms' organizational capabilities (Gibbons \& Henderson, 2012; Mouzas and Blois, 2013).

Thirdly, marketers and purchasers need to be aware that although interaction will determine the achievement of consent, the currency that actors bring into this interaction process is their

entitlements or access to resources. Actors' entitlements are not restricted to the ownership of physical resources such as products, production capacity or distributional resources. Entitlements may refer to intellectual assets, capabilities, brands, patents and innovation. By building a pool of resources that is unique, creative and original, organizations improve the currency that they bring to this interactive and time-consuming process of building consent in business marketing.

\section{CONCLUSION}

The paper has highlighted the mediating role of consent in business marketing. The paper provides insights into an interactive practice of consent between variously interconnected counterparts. The data emphasizes the value of re-defining the concept of choice (Buchanan, 2001; Williamson, 2002) away from its usual associations with discrete and independent decision-making and rational planning towards the idea of choice being part of an evolutionary discursive practice of proposal, response and re-response (Dyer \& Singh, 1998; Sarasvathy, 2001; Seidl, 2007; Johanson \& Vahlne, 2011). In this interpretation, business marketing in relationally embedded organizations involves the actors in webs of interdependent relationships, patterns of recursive interactions and constellations of heterogeneously 
distributed resources and competences. The outcomes of companies' choices are contingent upon the consent of their counterparts and this consent is not an instantaneous event with hard edges of yes and no. The study provides evidence that the opportunities that actors discover are idiosyncratic (Denrell et al., 2003) in their particular relational space and their pursuit over time is conditioned by an interactive and reciprocal practice of consent in which actors' interactions and resources, and the actors themselves, co-evolve to produce the events that we observe (Sarasvathy, 2001). This interactive and reciprocal practice of seeking and giving of actors' consent is often not visible, and it is not given to us transparently; it lies under the surface of observed events, which ostensibly appear as the result of actors' choice (Buchanan, 2001; Williamson, 2002).

The complexity of the opaque processes of business marketing make it possible that researchers and business managers may underestimate the interactive and time-consuming nature of seeking and reaching consent. The study makes it clear that business marketing is not simply a program that actors develop and choose to apply. The success of actors' choices is triggered only in conducive circumstances, which depend on the consent of counterparts. The mediating role of consent means that successful business marketing depend on providing the rationales and resources for other actors to react in compatible directions and seize contingent opportunities. Hence, it appears that consent rests on some form of wholeness and coherence. Productive consent requires the integration of contextual potentials and internal capabilities, the synchronization of short-term and long-term considerations, the co-existence of cooperation and competition, the harmonization of the general and the specific, and the symbiosis of the past and the future. 


\section{LIMITATIONS AND DIRECTIONS FOR FUTURE RESEARCH}

The current study has been limited to an investigation of manufacturer-retailer networks in the fast-moving consumer goods. These business networks demonstrate a high degree of connectivity among organizations that engage in continuing business relationships and depend on the resources of their counterpart retailers or manufacturers to address consumers' constantly evolving demand for products and services. It would be valuable to investigate interactive practice of consent in different contexts. What kind of insights can we gain that display different levels of collaboration and competiveness? Voluntary and informed consent appears highly relevant in financial industries, as well as in online transactions or mobile phone applications. As the constellations of actors, resources and interactions vary in these industries, we may posit that the nature and process of consent will differ. The role of consent can only be studied over recursive time. Recursive time captures the idea of continuity expressed in recursive practices, the pre-eminence of repetitions and organizational habits, as well as institutionalized forms of fixed sequences of interactions. Future research need to pay more attention to interactive practices over recursive time such as recurrent meetings, periodic business reviews, periodic task reviews, annual operating plans or periodic contract negotiations (Jarzabkowski \& Seidl, 2008). This direction of future research on consent could be linked with the capability of firms to learn how to contract and perform in continuing business relationships (Mayer \& Argyres, 2004; Mouzas, 2016) 


\section{REFERENCES}

Anderson, J.C., Håkansson, H., \& Johanson, J. (1994). Dyadic business relationships within a business network context. Journal of Marketing, 58, 1-15.

Ansoff, H.I. (1970). Corporate strategy: An analytic approach to business policy for growth and expansion. Penguin books.

Bar-Gill, O. (2012). Seduction by contract: Law, economics, and psychology in consumer markets. Oxford University Press.

Barnett, R.E. (1986). A consent theory of contract. Columbia Law Review, 86 (2), 269-321.

Barnett, R.E. (1992). The sound of silence: Default rules and contractual consent. Virginia Law Review, 78, 829-859.

Barney, J. (1991). Firm resources and sustained competitive advantage. Journal of Management, 17(1), 99-120.

Beckert, J. (1999). Agency, entrepreneurs, and institutional change. The role of strategic choice and institutionalized practices in organizations. Organization Studies, 20(5), 777-799.

Bhaskar, R. (1978). A realist theory of science. Hemel Hempstead: Harvester Press.

Borgatti, S. P., \& Foster, P. C. (2003). The network paradigm in organizational research: A review and typology. Journal of Management, 29(6), 991-1013.

Brennan, R., \& Turnbull, P.W. (1999). Adaptive behavior in buyer-supplier relationships. Industrial Marketing Management, 28(5), 481-495

Buchanan, J. M., \& Tullock, G. (1999). The Calculus of Consent: Logical Foundations of Constitutional Democracy. Vol. 3 The Collected Works of James M. Buchanan. Indianapolis, Ind.: Liberty Fund.

Buchanan, J.M. (1979). Cost and choice: An inquiry in economic theory. University of Chicago Press. 
Buchanan, J.M. (2001). Game Theory, Mathematics, and Economics. Journal of Economic Methodology, March 8: 27-32.

Caldwell, R. (2005). Things fall apart? Discourses on agency and change in organizations. Human Relations, 58(1), 83-114.

Child, J. (1997). Strategic choice in the analysis of action, structure, organizations and environment: retrospect and prospect. Organization Studies, 18(1), 43-76.

Cho, T.S. \& Hambrick, D.C. (2006). Attention as mediator between top management team characteristics and strategic change: the case of airline deregulation. Organization Science, 17, 453-469.

Davidsson, P., Delmar, F., \& Wiklund, J. (2006). Entrepreneurship and the Growth of Firms. Elgar Publishing, UK.

Day, G.S. (2000). Managing market relationships. Journal of the Academy of Marketing Science, 28(1), 24-30.

De Rond, M., \& Thietart, RA. (2007). Choice, chance, and inevitability in strategy. Strategic Management Journal, 28(5), 535.

Denrell, J., Fang, C. \& Winter, S. (2003). The economics of strategic opportunity. Strategic Management Journal, 24(10), 977-990.

Donaldson, T., \& Dunfee, T. W. (1994). Toward a unified conception of business ethics: Integrative social contracts theory. Academy of management review, 19(2), 252-284.

Dyer, JH., \& Singh, H. (1998). The relational view: Cooperative strategy and sources of interorganizational competitive advantage. Academy of Management Review, 23(4), 660-679.

Eisenhardt, K.M., \& Graebner, M.E. (2007). Theory Building from Cases: Opportunities and Challenges. Academy of Management Journal, 50(1), 25-32. 
Fehr, Hart \& Zehnder, (2011). Contracts as Reference Points-Experimental Evidence. American Economic Review, 101(2): 493-525.

Ford, D., \& Håkansson, H. (2006). The idea of interaction. The IMP Journal, 1(1), 4-27.

Ford, D., \& Håkansson, H. (2013). Competition in business networks. Industrial Marketing Management, 42(7), 1017-1024.

Ford, D., \& Mouzas, S. (2010). Networking under uncertainty: Concepts and research agenda. Industrial Marketing Management, 39(6), 956-962.

Ford, D., \& Mouzas, S. (2013). Service and Value in the Interactive Business Landscape Industrial Marketing Management, 42, 9-17.

Ford, D., Gadde L-E., Håkansson H. and Snehota I., (2011). Managing Business Relationships, $3^{\text {rd }}$ Edition. Chichester, John Wiley and Sons.

Freeman, R.E. (1984). Strategic Management: A stakeholder Perspective. Boston: Pitman.

Gibbert, M., Ruigrok, W., \& Wicki, B. (2008). Research notes and commentaries what passes as a rigorous case study. Strategic Management Journal, 29(13), 1465-1474.

Gibbons, R., \& Henderson, R. (2012). Relational Contracts and Organizational Capabilities. Organization Science, 23(5): 1350-1364.

Giddens, A. (1984). The constitution of society: Outline of the theory of structuration. University of California Press.

Goffman, E. (1959). The Presentation of Self in Everyday Life. New York: Doubleday. Goffman E. 1967. Interaction Ritual. Garden City, NY: Anchor.

Granovetter, M. (1985). Economic action and social structure: The problem of embeddedness. The American Journal of Sociology, 91(3), 481-510.

Håkansson, H., \& Snehota, I. (1989). No business is an island: the network concept of business strategy. Scandinavian Journal of Management, 5(3), 187-200. 
Håkansson, H., \& Snehota, I. (1995). Developing Relationships in Business Networks. London: Thomson International.

Håkansson, H., Ford, D., Gadde, L. -E., Snehota, I., Waluszewski, A. (2009). Business in Networks. Chichester: John Wiley.

Håkansson, H., Olsen, P., \& Bakken, T. (2013). Agency and economizing in interacted economies. IMP Journal, 7(2):106-111 Emerald Publishing Group.

Hamel, G., \& Prahalad, C.K. (1990). Corporate imagination and expeditionary marketing. Harvard Business Review, 69(4), 81-92.

Hart, O., \& Moore, J. (2008). Contracts as Reference Points. Quarterly Journal of Economics, 123: $1-48$.

Hite, J.M., \& Hesterly, W.S. (2001). The evolution of firm networks: From emergence to early growth of the firm. Strategic Management Journal 22(3), 275-286.

Hoffmann, A. O., \& Broekhuizen, T. L. (2010). Understanding investors' decisions to purchase innovative products: Drivers of adoption timing and range. International Journal of Research in marketing, 27(4), 342-355.

Howard, J. (1957). Marketing management: Analysis and decision. Homewood, Richard D. Irwin.

Jarzabkowski, P., \& Seidl, D. (2008). The role of meetings in the social practice of strategy. Organization Studies, 29(11), 1391-1426.

Johanson, J., \& Vahlne, J. E. (2011). Markets as networks: implications for strategy-making. Journal of the Academy of Marketing Science, 39(4), 484-491.

Kelley, E. \& Lazer, W. (1958). Managerial marketing: Perspectives and viewpoints. Homewood, Richard D. Irwin.

Kirzner, I. (1997). Entrepreneurial discovery and the competitive market process: An Austrian approach. The Journal of Economic Literature, 35, 60-85. 
Kotler, P., (1967). Marketing Management: Analysis, Planning and Control. Englewood Cliffs (NJ), Prentice Hall.

Lusch, R.F., Vargo, S.L., \& Tanniru, M. (2010). Service, value networks and learning. Journal of the Academy of Marketing Science, 38(1), 19-31.

Mantere, S., \& Vaara, E. (2008). On the problem of participation in strategy: A critical discursive perspective. Organization Science, 19(2), 341-358.

Markovits, D. (2004). Contract and collaboration. The Yale Law Journal 113, 1417-1518.

Mayer, K. J., \& Argyres, N. (2004). Learning to contract: Evidence from the personal computer industry. Organization Science, 15(4), 394-410.

McCarthy, E. (1960). Basic marketing. A managerial approach. Homewood, Richard, D. Irwin.

Mnookin, R.H., Peppet, S.R., \& Tulumello, A. (2000). Beyond winning: Negotiating to create value in deals and disputes. Cambridge, MA: Harvard University Press.

Mouzas, S. (2016). Performance based contracting in long-term supply relationships. Industrial Marketing Management, 59, 50-62.

Mouzas, S., \& Blois, K. (2013). Contract research today: Where do we stand? Industrial Marketing Management, 42(7), 1057-1062.

Nowak, M. (2006). Evolutionary dynamics. Cambridge, MA: Harvard University Press.

Nowak, M. (2011). Super Cooperators: Altruism, Evolution, and Why We Need Each Other to Succeed. New York: Free Press.

Ostendorf, J., Mouzas, S., \& Chakrabarti, R. (2014). Innovation in business networks: The role of leveraging resources. Industrial Marketing Management, 43(3), 504-511.

Pettigrew, A.M. (2014). The politics of organizational decision-making. Routledge.

Porter, M. (1981). The contributions of industrial organization to strategic management. Academy of Management Review, 6(4), 609-620. 
Porter, M. (2008). Competitive strategy: Techniques for analyzing industries and competitors. Simon and Schuster.

Ragin, C. C., \& Becker, H. S. (Eds.). (1992). What is a case? Exploring the foundations of social inquiry. Cambridge university press.

Ring, P.S., \& Van de Ven, A.H. (1992). Structuring cooperative relationships between organizations. Strategic Management Journal, 13(7), 483-498.

Sarasvathy, S.D. (2001). Causation and effectuation: Toward a theoretical shift from economic inevitability to entrepreneurial contingency. Academy of Management Review, 26 (2), 243-263.

Sayer, A. (2000). Realism and Social Science. London: Sage.

Scarry, E. (2014). Thermonuclear monarchy: choosing between democracy and doom. WW Norton \& Company.

Sebenius, J. K. (2013). Level Two Negotiations: Helping the Other Side Meet Its "Behind-theTable” Challenges. Negotiation journal, 29(1), 7-21.

Seidl, D. (2007). General strategy concepts and the ecology of strategy discourses: A systemicdiscursive perspective. Organization Studies, 28 (2), 197-218.

Silverman, D. (2000). Doing Qualitative Research: A Practical Handbook. Sage, London.

Sminia, H., \& De Rond, M. (2012). Context and action in the transformation of strategy scholarship. Journal of Management Studies, 49(7), 1329-1349.

Sorescu, A. B., Chandy, R. K., \& Prabhu, J. C. (2003). Sources and financial consequences of radical innovation: Insights from pharmaceuticals. Journal of Marketing, 67(4), 82102.

Tan, J., \& Tan, D. (2005). Environment-strategy co-evolution and co-alignment: A staged model of Chinese SOEs under transition. Strategic Management Journal, 26(2), 141. 
Tsoukas, H. (1989). The validity of idiographic research explanations. Academy of Management Review, 14(4), 551-561.

Uzzi, B. (1997). Social structure and competition in interfirm networks: The paradox of embeddedness. Administrative Science Quarterly, 42(1), 37-70.

Uzzi, B., \& Lancaster, R. (2003). Embeddedness and learning: The case of bank loan managers and their clients. Management Science, 49(4), 383-400.

Vaara, E., Kleymann, B., \& Seristö, H. (2004). Strategies as discursive constructions: The case of airline alliances. Journal of Management Studies, 41(1), 1-35.

Vaara, E., \& Tienar, J. (2008). A discursive perspective on legitimation strategies in multinational corporations. Academy of Management Review, 33(4), 985-993.

Venkatraman, N., \& Camillus, J.C. (1984). Exploring the concept of "fit" in strategic management. Academy of Management Review, 9(3), 513-525.

Villas-Boas, J.M., \& Zhao, Y. (2005). Retailers, manufacturers, and individual consumers: Modeling the supply side in the ketchup marketplace. Journal of Marketing Research, 42(1), 83-95.

Volberda, H.W., \& Lewin, A.Y. (2003). Co-evolutionary Dynamics Within and Between Firms: From Evolution to Co-evolution. Journal of Management Studies, 40(8), 21112136.

Williamson, OE. (2002). The Theory of the Firm as Governance Structure: From Choice to Contract. The Journal of Economic Perspectives, 16(3), 171-195.

Zaheer, A., \& Venkatraman, N. (1995). Relational governance as an interorganizational strategy: An empirical test of the role of trust in economic exchange. Strategic Management Journal, 16(5), 373-392.

\section{Figure 1: Manufacturer-Retailer Network}




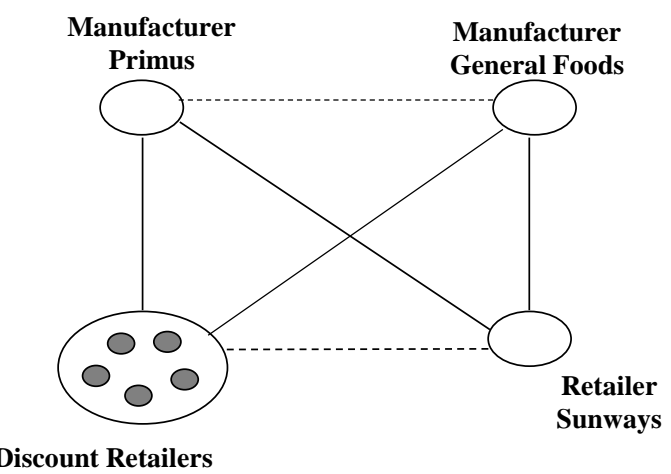

Table 1: Overview of Data Collection

\begin{tabular}{|l|l|}
\hline Companies/ Group of companies & 4 Manufacturers and retailers \\
\hline Respondents & 12 Managers \\
\hline Field observations & 78 Chats, Meetings, Events \\
\hline Press releases & 267 Press Releases \\
\hline Annual reports & 8 Annual reports \\
\hline Manifestations of consent & 28 Framework Agreements \\
& \\
\hline
\end{tabular}

Table 2: Respondents' Business, Background and Function 


\begin{tabular}{|c|c|c|c|c|}
\hline Companies & Business & $\begin{array}{l}\text { Capabilities/ } \\
\text { Experience }\end{array}$ & Respondents & Role \\
\hline Primus & Manufacturer & $\begin{array}{l}\text { Branded full- } \\
\text { priced snack food } \\
\text { products }\end{array}$ & $\begin{array}{l}\text { Klaus } \\
\text { Edward } \\
\text { Wolf }\end{array}$ & $\begin{array}{l}\text { KAM } \\
\text { Marketing } \\
\text { Production }\end{array}$ \\
\hline General Foods & Manufacturer & $\begin{array}{l}\text { Private labels and } \\
\text { value food } \\
\text { products }\end{array}$ & $\begin{array}{l}\text { Dieter } \\
\text { John } \\
\text { Johann }\end{array}$ & $\begin{array}{l}\text { KAM } \\
\text { Finance } \\
\text { R\&D }\end{array}$ \\
\hline Sunways & Retailer & $\begin{array}{l}\text { Hyper-market } \\
\text { outlets }>4000 \mathrm{~m}^{2} \\
\text { Full-Assortment }\end{array}$ & $\begin{array}{l}\text { Franz Josef } \\
\text { Hans } \\
\text { Edith }\end{array}$ & $\begin{array}{l}\text { CM } \\
\text { Purchasing } \\
\text { Sales }\end{array}$ \\
\hline $\begin{array}{l}\text { Discount } \\
\text { Retailers }\end{array}$ & Retail group & $\begin{array}{l}\text { Discount outlets } \\
<4000 \mathrm{~m}^{2} \\
\text { Private labels } \\
\text { Value products }\end{array}$ & $\begin{array}{l}\text { Fritz } \\
\text { Stefan } \\
\text { Leon }\end{array}$ & $\begin{array}{l}\text { CM } \\
\text { Purchasing } \\
\text { Sales }\end{array}$ \\
\hline
\end{tabular}


Table 3: Evidence of Consent in Business Marketing

\begin{tabular}{|c|c|c|}
\hline $\begin{array}{l}\text { LAYERS OF } \\
\text { INTERACTION }\end{array}$ & $\begin{array}{l}\text { INITIAL SITUATION IN } \\
\text { NETWORK SPACE }\end{array}$ & $\begin{array}{l}\text { INTERACTION OVER } \\
\text { NETWORK TIME }\end{array}$ \\
\hline ACTORS & $\begin{array}{l}\text { - Existing jointness between } \\
\text { General Foods and Sunways } \\
\text { in developing value brands } \\
\text { and private labels } \\
\text { - } \\
\text { Existing jointness between } \\
\text { Primus and Sunways in } \\
\text { developing premium brands } \\
\text { - Existing jointness between } \\
\text { Discount Retailers and } \\
\text { General Foods seeking } \\
\text { value products/ private } \\
\text { labels }\end{array}$ & 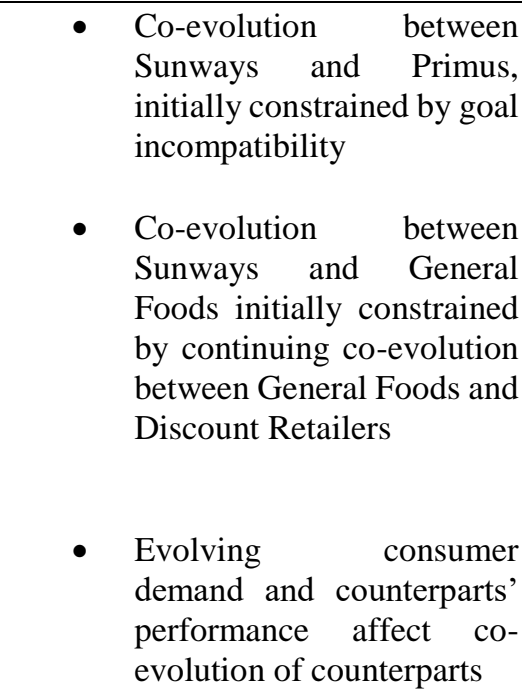 \\
\hline RESOURCES & $\begin{array}{l}\text { - Sunways lacks private label } \\
\text { resources } \\
\text { - General Food dependent on its } \\
\text { private label resources and } \\
\text { relationships with Discounters. } \\
\text { - } \begin{array}{l}\text { Discount retailers lack brand } \\
\text { resources. }\end{array}\end{array}$ & $\begin{array}{l}\text { - Sunways pursuit of private label } \\
\text { resource depends on continuing } \\
\text { interaction with two available } \\
\text { manufacturers. } \\
\text { - General Food considers the } \\
\text { development of exclusive } \\
\text { brands as way to reduce } \\
\text { dependency on its private label } \\
\text { products. } \\
\text { - General Food's development of } \\
\text { branded products depends on } \\
\text { Sunways' interactions with } \\
\text { Primark and subsequently } \\
\text { Primark's consent to transfer } \\
\text { property rights for } 5 \text { years } \\
\text { - } \\
\text { Discount Retailers' consider the } \\
\text { opportunity of discounted } \\
\text { brands only when this resource } \\
\text { was exploited by Sunways. } \\
\text { Extension of their resources } \\
\text { towards branded products } \\
\text { depends on manufacturers' } \\
\text { consent to discount their brands }\end{array}$ \\
\hline & $\begin{array}{l}\text { - Sunways retail operations are } \\
\text { negatively affected by Discount } \\
\text { Retailers performance }\end{array}$ & $\begin{array}{l}\text { - Sunways' development of } \\
\text { private labels depends on its }\end{array}$ \\
\hline
\end{tabular}




\begin{tabular}{|c|c|c|}
\hline ACTIVITIES & $\begin{array}{l}\text { - General Food's development of } \\
\text { branded products emerges as a } \\
\text { result of failed Sunways-Primus } \\
\text { interactions } \\
\text { - Primus discovers the opportunity } \\
\text { to develop a discounted mega- } \\
\text { pack for Sunways only when } \\
\text { business hemorrhage was } \\
\text { unstoppable } \\
\text { - Discount Retailers discover the } \\
\text { opportunity of discounted brands } \\
\text { when market evidence emerged } \\
\text { that Sunways venture was } \\
\text { succeeding }\end{array}$ & 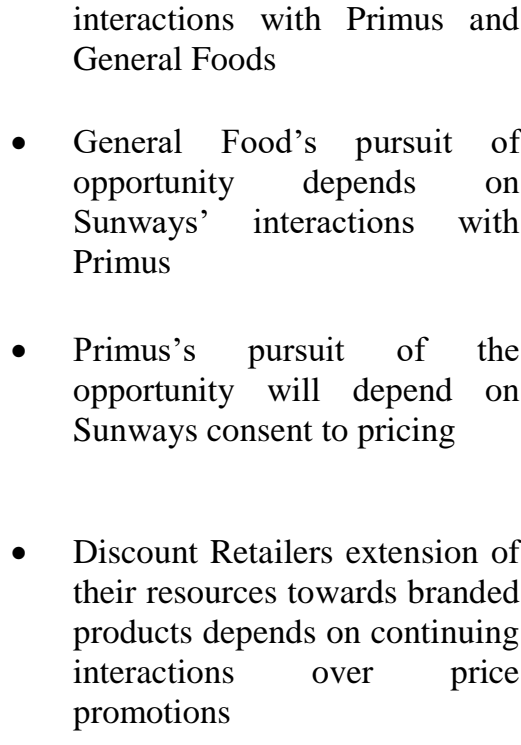 \\
\hline
\end{tabular}

Håkansson et al., 2013 ; Johanson, J., \& Vahlne, J. E. (2011). Ford, D., Gadde L-E., Håkansson

H. and Snehota I., (2011). Ostendorf, et al., 2013 